\title{
Perceptions of a Surgical Team About the Ethical and Legal Responsibilities of Forgetting Foreign Bodies in Patient Bodies and Other Errors
}

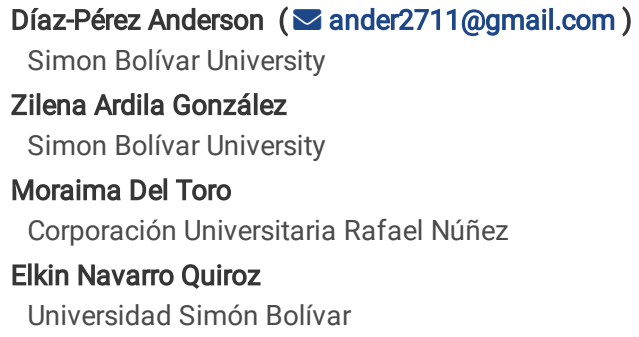

\section{Research Article}

Keywords: medical errors, ethics, medical: liability, legal, retained surgical item, textileoma, gossypiboma, surgical equipment, defensive medicine, foreign bodies, perception

Posted Date: March 17th, 2021

DOI: https://doi.org/10.21203/rs.3.rs-294286/v1

License: @ (i) This work is licensed under a Creative Commons Attribution 4.0 International License. Read Full License 


\section{Abstract}

Background: Retained surgical items (RSIs) represent a real and ongoing problem, but it is preventable. Its real incidence is unknown because of underreporting resulting from the fear of lawsuits for medical errors. This study aimed to describe the perception of the members of a surgical team about their ethical and legal responsibilities related to medical errors, specifically concerning the presence of RSIs.

Methods: This qualitative, descriptive, and interpretative study focused on the perceptions of the members of a surgical team on the ethical and legal problems they may face because of the presence of RSIs. Continuous saturation sampling was performed by interviewing 17 professional members of the surgical team. Atlas Ti $8.0 \AA$ program was used for analyzing the data obtained. It traced the categories by means of content analysis of the perceptions and practices during possible ethical and legal responsibilities because of medical errors.

Results: The interviewees were conflicted between complicity and justice, as it is a duty to report events or actions that put the lives of surgical patients at risk.

Conclusions: The lack of awareness about the rules and believing that human errors are inevitable lead to normalizing errors, which does not allow professionals to face the risk and, therefore, to avoid it.

\section{Background}

Oblito is derived from the Latin "Gossipium" which means "cotton" and "Boma" which identifies the "place where something is hidden or disguised" [1,2]. The term oblite is known by different names, in Mexico, Chile, Colombia, Bolivia, Argentina and Brazil as "textiloma", "gossypiboma", "gasomas", "oblitomas", these words refer to the type of material found in the patient's cavity [1].

RSIs are a real and ongoing problem, but it is preventable. It is detrimental to the safety of a surgical patient [3-6]. The incidence of this type of error remains largely unknown because of the underreporting of cases by professionals to avoid the potential risk of lawsuits [7]; therefore, the actual number of cases is not reported, making it a problem difficult to pinpoint [2]. Avoiding this type of error becomes a major challenge for members of a surgical team, as they must not only ensure the success of the procedure but also avoid litigation because of the presence of RSIs among other types of medical errors [8-10].

In Colombia, surgeons as well as surgical technicians must carefully count the materials placed on an instrument table, especially gauzes [11]. The mechanisms or processes mostly used to avoid medical errors such as RSIs are as follows: periodic and constant counting during a surgery, depending on its type and duration; discarding incomplete or excess packages, maintaining a constant number of gauzes that is known to all members of the surgical team; and maintaining a tidy instrument table throughout the surgery to facilitate the counting of surgical materials and instruments [11].

Statistically, an RSI occurs in 1 out of 100 to 1 out of 3,000 surgeries [1,2]. In Colombia, according to reports, it occurs in $0.3 \%-1 \%$ of 1,000 surgeries [12], being more frequent in women than in men because of the frequency of gynecological procedures. Globally, it is believed to range from $1 \times 1,300$ to $1 \times 1,500$ only for abdominal surgeries. Other sources reveal an occurrence that reaches $1 \times 3000$ among all surgical interventions $[1,7,13,14]$. Among the most frequent factors for the occurrence of an adverse event are prolonged surgeries, thoracic surgeries where the instruments used are small, staff fatigue, and the lacks of shift interruption and communication, among others [15,16].

It is important to consider that any medical act related to an adverse event occurred during a surgical procedure, such as forgetting a foreign body inside a patient after surgery, implies administrative, deontological, civil, and even criminal liabilities of the surgical team. These liabilities can be individual or combined [11,17-19].

Studies have shown that there is a blurred line between a surgical team's knowledge and practices and their responsibilities regarding RSIs; it remains unclear whether a negligence of action can be explained by the lack of surgical awareness $[10,20]$. It is pertinent to note that malpractice claims began to emerge in the 1900s as a "tempting new growth area for aggressive lawyers" because of the frequency of X-ray use [21].

Studies related to the medical responsibilities of RSIs are classified as medical malpractice; This topic has been approached from a quantitative perspective, which leaves gaps that can be addressed from qualitative research in the understanding or dynamics of the phenomenon in terms of perceptions and symbologies from their social imaginaries that are reflected in some practices [22-25].

Conversely, qualitative studies seek understanding rather than a prediction for a phenomenon because of its complexity, especially when it involves some degrees of legal responsibility perceived by the members of a surgical team when confronted with ethical and legal problems [21,26-30]. Therefore, the following question arises: is it necessary to inform the patient about the error? The answer is conditioned to the knowledge but also to the perceptions that health care professionals have about legal implications. This implies to maximize the safety measures established before, during, and after a surgery [31], thus avoiding permanent or temporary disabilities or even the death of the patient, as RSI extraction surgery may be more complicated than the original surgery [32].

In a study conducted by Córdova et al., an anonymous survey was conducted on 93 surgeons. The results showed that $32 \%$ of the surgeons acknowledged having left a gauze pad in the patient abdominal cavity during one of their surgeries, $80 \%$ stated that they had already handled an RSI, and $94 \%$ acknowledged knowing a colleague who had made this technical error [31]. The authors also evaluated the degree of responsibility of the medical team. According to the surgeons, the responsibility fell on themselves; for the surgeons who had not forgotten the gauze, the responsibility was attributed to the surgical technician [31]. However, from the surgeons' perspective, the individual primarily responsible for this type of error is the surgical technician with 293 points, surgeon with 285 points, operating room nurse with 165 points, and finally, the assistant with 76 points [31]. 
Our study aimed to describe (from a qualitative perspective) the perceptions that members of a surgical team have about their ethical and legal responsibilities related to medical malpractice, specifically concerning RSIs.

\section{Methods}

This was a qualitative, descriptive, and interpretative study. This study aimed to focus on the perceptions of the members of a surgical team to describe their views on the ethical and legal problems that they may face because of forgetting foreign bodies in a patient body, among other types of medical errors considered real malpractices. An interview was designed which was validated through the evaluation of experts in the area of psychology, medicine, and surgical instrumentalists. Continuous saturation sampling was performed, thus allowing us to gather perceptions of the professionals according to their age, gender, and professional profile. Finally, interviews were conducted with 17 members of a surgical team. The participants were informed about the objectives of the research; once they understood the information about the study and its impact, the interviewees signed the informed consent, which was approved by the research committee of the Surgical Instrumentation Program of the Universidad Popular del Cesar and the ethics and extension committee of the Institutional Tertiary Provider of Health.

The participants were informed about the objectives of the research; once they understood the information about the study and its impact, the interviewees signed the informed consent, which was approved by the research committee of the Surgical Instrumentation Program of the Universidad Popular del Cesar and the ethics and extension committee of the Institutional Tertiary Provider of Health. The committee determined that the project conformed to resolution $8430 / 93$ of the CONPES document in Colombia, considering it a risk-free investigation. It also responded to the elements of safeguarding the confidentiality of the information provided by the participants, such as the taking of consent as stipulated by international regulations and declarations such as Manzini, Belmont and Helsinki. Data were collected through semi-structured scripted interviews, which lasted approximately 45-60 min. These comprised open-ended questions regarding the perception of the members of the surgical team about the perceived liabilities when they get involved in a medical malpractice process caused by RSIs, classification of medical errors, and principles of bioethics when facing ethical and legal responsibilities. These questions were validated by experts who assessed two dimensions: responsible medicine and defensive medicine.

All interviews were audio-recorded and transcribed verbatim, and the names and surnames, specialization, or profession were removed from the transcriptions to preserve the participants' anonymity. Data were analyzed taking into account the open and emerging categories (thematic coding) in the context by means of content analysis. To improve reliability, transcripts were read independently by three researchers with expertise in surgery, education, and medical law.

The Atlas Ti $8.0 \AA$ program was used to track and identify the most common patterns and categories. These were analyzed in the context of the perceptions of the interviewees to describe and interpret the causes and possible explanations of their actions when facing a possible ethical and legal responsibility for a medical error, specifically concerning an RSI.

\section{Results}

\section{Ethical and legal responsibilities, negligence as the primary cause of error, and the importance of clinical records}

Those interviewed regarding ethical and legal responsibilities described that their main fear is the institutional repercussions (administrative liability), which could lead to possible dismissal, including the loss of their professional card (deontological liability). The members of the surgical team were unsure about the probability of a complaint going directly to the government authorities, especially in cases where a foreign body could have caused a permanent or temporary disability or even the death of the patient.

When a colleague commits an error, initially the person involved is held responsible for their mistake; then, the responsibility escalates to the immediate supervisor and then to human resources, going up to the authorities that should come depending on the type of problem. (Coded Voice [3:6]).

Well, the legal part is something extremely delicate, and it would imply the loss of our license to keep working. (Coded Voice [8:3]).

Negligence was the primary error mentioned by the members of the surgical team, especially the careless management of the patient because of misinformation and poor writing of medical records (MRs); eventually, MRs end up not being a reliable document when making decisions regarding the surgical protocol. Inexperience was also found to be related to emergency procedures, as well as poor management of personal problems as a cause of a possible miscounting of elements and instruments before, during, and after the surgical procedure.

There are several causes, ranging from poor patient preparation, patient misinformation, emergency procedures, poorly written medical records, and personal problems, that could lead to forgetfulness during a procedure. (Coded Voice [3:4]).

In relation to the clinical records as a conditioning element in the actions of the members of the surgical team and as evidence in a medical liability process aiming at proving a medical malpractice, it was found that MRs do not describe the error, pointing at ignorance of the norm or failure to comply with it as the main possible reason. Some members of the surgical team described the low institutional requirement for reading MRs, recognizing the high probability of making an error (actual malpractice). In addition to these elements, there are other factors such as emergency surgery, shift changes, work monotony and inappropriate application of the checklist, work stress, and the normalization of errors (daily errors), among others.

I think emergency surgeries are the main reason, as well as shift changes that are not delivered in a correct way. (Coded Voice [15:4]).

Monotony, insecurity at the time of starting the procedure, stress from the doctor, some emotional problems. (Coded Voice [16:2]).

Page $3 / 9$ 


\section{Complicity and bioethical principles}

The interviewees were conflicted between the principles of respect and justice, which makes it their medical duty to report events or actions (of their own or colleagues) that put a patient's life at risk. In other words, professional secrecy should not be confused with complicity. Conversely, the principle of justice holds the medical professional responsible for maintaining silence and not reporting an error caused by a team member, which must be reported and described in the clinical records in detail.

I would not report it because everyone should know his or her own responsibilities. (Coded Voice [7:5]).

Well, in this case, since we are talking about a colleague, I personally would not report it, but I would talk to the colleague and let them be the one to report the case to the immediate supervisor. (Coded Voice [17:5]).

\section{Surgical awareness in preventing medical errors concerning RSIs}

Surgical awareness was reflected in the conscientiousness and thoughtfulness of the actions of the members of the surgical team as they made corrective actions to avoid errors. They recognized that human nature is influenced by factors that can lead to errors such as leaving a foreign body in the patient body or even failing to report it.

In our medical practice, we are still human and we can make mistakes at any moment, but if we are aware and we realize in time that we are doing a bad procedure, we must verify, count, and alert all personnel to reduce risks and provide greater patient safety. (Coded Voice [3:3]).

First, you try to talk to your colleague and tell them what happened to try to find a solution, and if you do not find a solution, you report it to your supervisor. (Coded Voice [4:5]).

If the error happens during the surgical procedure and you realize it immediately, you must inform the physician about the problem; if you realize after the surgical procedure, you must also inform the physician and request the corresponding radiological studies to verify the existence of the foreign body. (Coded Voice [15:3]).

\section{Conflict about responsibility related to their professional ethics}

There is a conflict among medical professionals about liabilities in the lack of surgical awareness related to the measures taken to avoid causing harm to patients and thus avoiding being punished, even when they may be accused of complicity. That is, they do not prioritize the welfare of the patient but their own interest, and this is caused by the fear of being involved in something similar to the presence of an RSI. They may even come to believe that the responsibility is individual, which is not far from reality. It should be stressed that, as the members of a surgical team, they are all part of the team; therefore, they have a common goal, which is the safety and quality of the surgical procedure performed for the welfare of the patient. In this context, it is fundamental to point out the importance of taking into account the attitude toward responsibility that health care professionals have with their work in practice, in addition to the possible psychological damages of doubting if it was really a single foreign body, generating anxiety, and thus affecting the recovery of the surgical patient.

The main fear is the harm we will cause to the patient and the negative effects that malpractice will have on the patient, as well as the legal implications. (Coded Voice [3:8]).

That the patient suffers from complications or dies because, if something happens to them, it can also affect me. (Coded Voice [6:3]).

Another important element is the fact that members of the surgical team confused social values with professional ethics. They considered that ethics are innate to human nature, meaning that we are somehow born with it or we bring ethics from home, and therefore, it does not need to be taught at the professional level. It should be noted that social values help us generate different affective bonds, as they are taught in our first circle of socialization, such as family; , humans build their own criteria through the years, and therefore, they know the good and bad within the framework of professional ethics.

It is of utmost importance to consider ethical principles in our profession. They should be embodied in our lives. We learn them at home and they mature as we grow. (Coded Voice [3:1]).

I do not think so, as we all learn those principles at home. (Coded Voice [17:2]).

\section{Education, an important element in recognizing medical errors}

Education was found to be related to professional ethics. The members of the surgical team recognized that education allows them to recognize and reflect on the differences between real and apparent malpractices.

Ethics is what makes us. If professionals do not have ethics, they are not able to behave responsibly as such and they will make multiple errors in their practice, where patients will be the most harmed party. (Coded Voice [11:2]). 
Yes, as when professionals are trained, they are taught the principles; then, they will be qualified professionals who will always act by the principles of good faith and efficiency to provide a service within the best conditions. (Coded Voice [15:2]).

\section{Important principles to avoid medical errors, especially forgetting a foreign body in patient bodies}

Most of the members of the surgical team described responsibility as an important principle to fully comply with the processes and protocols that safeguard patient safety. Other important principles are as follows: caution and confidentiality in not disclosing the patient's clinical or personal information to personnel not directly involved in the surgical process; entrusting the team to have everything prepared according to the conditions of the patient and institution, ultimately giving peace of mind to everyone involved; self-discipline to continue educating themselves to become more and more aware of their responsibility to be able to predict and prevent risks and complications inherent to an RSI in the patient's body.

In our medical practice, we are still human and we can make mistakes at any moment, but if we are aware and we realize in time that we are doing a bad procedure, we must verify, count, and alert all personnel to reduce risks and provide greater patient safety. (Coded Voice [3:3]).

As professionals, our work is all about ethics; a professional without ethics is not fit to practice the profession as such, and a great deal of responsibility is required in this field. (Coded Voice [11:1]).

Principles make us qualified professionals who will always act by the principles of good faith and efficiency to provide a service within the best conditions. (Coded Voice [15:2]).

\section{Discussion}

It is clear that errors can occur in any hospital service; therefore, reflecting on the factors that cause these errors and acting accordingly are essential [33-36]. However, as it was evidenced, there is a tendency among the members of the surgical team to hide errors, both their own and those of their colleagues, either out of empathy or ignorance, primarily because of the fear of sanctions or lawsuits. Research shows that, when facing these actions, there is a clear lack of ethics related to patient safety, a practice of defensive medicine. Safety ethics considers it essential to reveal errors, including near misses or those without significant consequences, opting for an honest message reflected in the transparency of professional actions as evidenced in the present study with the following principles: respect, completeness, and honesty, as evidenced by other studies that support the idea of responsibility within the framework of surgical awareness [21,29,30,37-41].

The principle of responsibility was found in the actions regarding the adequate management of the functions of each of the surgical team members to avoid errors as much as possible, for example: the careful reading of the clinical records, participatory counting of the entire surgical team, board with the annotations of the counting of elements, and instruments, among others [26,42-44].

Continued education was particularly valuable in the analysis of this research, as it allows members of the surgical team to recognize the value of safe health care and minimize the probability of failures or errors by designing mechanisms or strategies that allow them to predict the likelihood of a medical error $[21,31,45,46]$.

It can be said that the interviewees recognize the need of knowledge in ethics and legal liabilities and the importance of applying such knowledge. However, as mentioned by Rojas Arroyo [47], Mario Bunge "defines knowledge as a set of ideas, concepts, and statements that can be clear and precise, ordered, vague, and inexact," but when it is rational, "it is constituted by concepts, judgments, and reasoning and not by sensations, images, behavior patterns, etc." [22]. Knowledge is acquired throughout life and experience and is complemented with the lessons learned at university, as described by Eiser, Floyd, and Kimball (quoted by Camarena Nuñez): "they define attitude as a learned predisposition to respond to a stimulus in different situations, which can be negative or positive" [48]. These conceptual elements were linked to the fact that many of the members of the surgical team, despite knowing how to perform their functions, limit themselves to what they consider humanly possible, leading them to commit errors, including those considered customary, such as not reading the clinical records or the limits between professional secrecy and complicity, among others. Several studies have mentioned that collaborative work is an important factor in reducing errors, as well as adherence to standards or protocols that promote patient safety in a surgical case $[1,9,11,12,19,21,42]$.

\section{Conclusions}

The members of the surgical team emphasized that their professional actions should be regulated by values and principles such as respect for patients and for their colleagues, thus implying a good treatment and surgical awareness in the ability to reflect on their professional skills in a situation where there is a probability of making a mistake such as leaving a foreign body in a patient body (RSI). However, there is a clear conflict between loyalty and complicity in one's own actions and those of a third party. This lack of transparency and honesty emerges when patient safety is weighed against the fear of legal sanctions: civil, criminal, administrative, and deontological.

Education was found to be one of the essential elements affecting how the members of the surgical team reacted when announcing, preventing, and correcting errors. The lack of this continuous training leads to conflicts of actions such as the limits between professional secrecy and complicity, which subsequently leads to sanctions depending on the extent of the action in terms of civil, administrative, deontological, criminal, and social responsibilities.

The lack of awareness about the rules and the belief that human errors are inevitable lead to some professionals normalizing the errors. This is an imprudent action, as it does not allow them to face the risk by means of designing new methods, protocols, or complementary tools that might allow them to predict and 
avoid errors.

Members of the surgical team considered MRs to be an important legal support document. However, surgical technicians describe that they do not feel obliged to read it in depth, although it is a deontological duty for doctors and nurses.

In general, surgical technicians showed a greater degree of ignorance because they were unclear about their individual and collective responsibilities as the members of a surgical team making a mistake. They show confusion and ignorance regarding whom, how, and where to notify of the error made, whether it is their own or that of a third party (colleague) member of the surgical team.

It is important to consider that administrative responsibility does not exempt professionals from the rest of the responsibilities, both civil and criminal. Only one interviewee mentioned the deontological dimension when describing their feelings about their fault leading to the withdrawal of their professional credentials. However, although surgical instrumentation does not have an approved deontological code, the actions of surgical team members can be analyzed by a medical ethics court that can sanction an error leading to a permanent or temporary disability or the death of the surgical patient.

The members of the surgical team recognized that ignorance does not exempt them from responsibilities; on the contrary, it makes it worse. In conclusion, they recognize the importance of continuing education and strengthening professional ethics with learning based on experience to avoid making mistakes, especially those because of carelessness related to not paying attention to the rules.

\section{Limitations}

Limitations were related to selective memory bias in the research subjects. In this sense, an attempt was made to control the bias by means of complementary questions to avoid, for example, participants remembering only negative or positive events, tending to exaggerate or embellish such an incidence.

\section{Abbreviations}

MR: Medical record

RSI: Retained surgical item

\section{Declarations}

\section{Ethics approval and consent to participate}

The participants were informed about the objectives of the research; once they understood the information about the study and its impact, the interviewees signed the informed consent, which was approved by the research committee of the Surgical Instrumentation Program of the Universidad Popular del Cesar and the ethics and extension committee of the Institutional Tertiary Provider of Health. The committee determined that the project conformed to resolution $8430 / 93$ of the CONPES document in Colombia, considering it a risk-free investigation. It also responded to the elements of safeguarding the confidentiality of the information provided by the participants, such as the taking of consent as stipulated by international regulations and declarations such as Manzini, Belmont and Helsinki.

The research was approved by the research committee of the Surgical Instrumentation Program and by the ethics and extension committee of the Institutional Provider where the research was conducted; these committees determined that the research complied with Resolution $8430 / 93$ of the Colombian Ministry of Health, classifying the study as risk-free.

The statements of Manzini (2000) and the Belmont Report (1979) establish the guidelines mentioned below, which were applied in the present study:

- Informing the participating members of the surgical team about the process for obtaining information and how interviews or other instruments will be coded to safeguard participant identity.

- The right to participate or not to participate and the right to withdraw from the study at any time, which was described in the informed consent.

- The confidentiality and anonymity of the interviewees.

- To inform about the objectives of the study and guarantee that the data will not be used for purposes other than those of this research, both verbally and in writing (informed consent).

- A sense of trust was established during the interview.

- Permission was requested to record conversations and transcribe information.

- Study participants were provided with a report on the results of the study, so that they could verify the elements indicated therein before the study is endorsed or published.

\section{Consent to publish}

Not applicable.

\section{Availability of data and materials}


The data sets generated and/or analyzed during the current study are not publicly available because we will conduct other analyses for which we expect future publications. We will also support other projects of students in graduate training. However, data are available from the corresponding author upon reasonable request.

\section{Competing interests}

The authors declare that they have no competing interests.

\section{Funding}

Research was conducted with the financial resources of the researchers and the logistical support of the participating institutions in relation to the software implemented, such as Atlas Ti $8.0{ }^{\circledR}$ and SPSS $19.0 \AA$.

\section{Authors' contributions}

The authors made important contributions:

ADP: In the conception and design of the research project, methodological design and support in the collection and analysis of information from the interpretation of the data that emerged from the programs used.

ZAG: In the writing of the article and in the critical revision of the same in elements such as style, as well as in updating information with intellectual content with due contrast of the results.

MTR: In the writing of the article and in the critical revision of the same in elements such as style, as well as in updating information with intellectual content with due contrast of the results.

ENQ: in the methodological design as a scientist in relation to the search for scientific information, in the design of the instrument and in the search for experts for its validation.

\section{Acknowledgments}

We would like to thank the surgical instrumentalists ANYELLI MISHELL CALDERÓN ORTEGA \& CLAUDIA PATRICIA PEREZ GÓMEZ, for their contribution in the application of the instruments to the research subjects, all members of the surgical team.

\section{References}

1. Acosta HDT. Panorama latinoamericano del cuerpo extraño olvidado en el interior del paciente, desde la vista del instrumentador quirúrgico. Cienc Salud Virtual [Internet]. 30 de diciembre de 2015 (citado 23 de enero de 2021);7:42-52. Available at:

https://revistas.curn.edu.co/index.php/cienciaysalud/article/view/517.

2. Ramírez GAM, Burgos OG, Lima JAC, García EV. Material quirúrgico olvidado: Gossypiboma, textiloma, gasoma. En: Anales de radiología, México. 2007. p. 285-96. Available at: https://www.medigraphic.com/cgi-bin/new/resumen.cgi?IDARTICULO=30420.

3. Rothrock JC. Alexander's care of the patient in surgery-e-Book. Elsevier Health Sciences; 2018. Available at: https://books.google.es/books? $\mathrm{hl}=$ es\&lr=\&id=04IIDWAAQBAJ\&oi=fnd\&pg=PP1\&dq=othrock+JC.+Alexander\%E2\%80\%99s+Care+of+the+Patient+in+Surgery-EBook\&ots=HEcNrjxC3V\&sig=1BUQKNAgGctHumK-8qT1UEBo9Zk.

4. Frenkl TL, Rackley RR, Vasavada SP, Goldman HB. Management of iatrogenic foreign bodies of the bladder and urethra following pelvic floor surgery. Neurourol Urodyn Off J Int Cont Soc. 2008;27:491-5. Available at: https://onlinelibrary.wiley.com/doi/abs/10.1002/nau.20558.

5. Lincourt AE, Harrell A, Cristiano J, Sechrist C, Kercher K, Heniford BT. Retained foreign bodies after surgery. J Surg Res. 2007;138:170-4. Available at: https://www.sciencedirect.com/science/article/pii/S0022480406004239.

6. Gonzalez-Ojeda A, Rodriguez-Alcantar DA, Arenas-Marquez H, Chavez-Perez R, Alvarez-Quintero R, Perea-Sanchez A. Retained foreign bodies following intra-abdominal surgery. Hepatogastroenterology. 1999;46:808-12. Available at: https://europepmc.org/article/med/10370618.

7. Balcázar-Rincón LE, Gordillo Gómez EA, Ramírez-Alcántara YL. Oclusión intestinal secundaria a oblito quirúrgico. Cir Cir [Internet]. 1 de noviembre de 2016 [citado 21 de enero de 2021];84(6):503-8. Available at: https://www.sciencedirect.com/science/article/pii/S0009741115002510.

8. Ojuka DK, Okutoyi L, Otieno FC. Communication in surgery for patient safety. En: Vignettes in Patient Safety-Volume 4. Intech0pen; 2019:31-51 Available at: https://books.google.es/books?

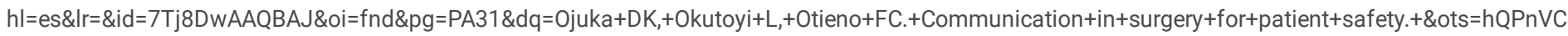
UQ8eexKIOguwwEiJ6uQ.

9. Higham H, Vincent C. Human error and patient safety. En: Textbook of patient safety and clinical risk management. Springer, Cham; 2021. p. 29-44. Available at: https://library.oapen.org/bitstream/handle/20.500.12657/46117/2021_Book_TextbookOfPatientSafetyAndClin.pdf?sequence=1\#page=40. 
10. Vincent C. The essentials of patient safety. Download Dispon All'indirizzo Www1 Imp Ac Ukmedicineaboutinstitutespatientsafetyservicequality. 2012. Available at: http://qi.speedwaystaging.co.uk/wp-content/uploads/2014/08/r_04-vincentessentialsofpatientsafety1.pdf.

11. Díaz-Pérez A, Peralta YJG, Montero HM, Castaño CP, Acosta BV, Rodriguez TC. Legal implications for actions considered iatrogenic: Knowledge and practices of the surgical team, Valledupar, Cesar/Colombia. Glob J Health Sci. 2020;12:1-90. Available at: https://pdfs.semanticscholar.org/45db/3a50ba9a37497b34170996c31c7a476ac405.pdf.

12. Berro G. oblito,?’ responsabilidad colectiva o? Aspectos médico-legales; 2009 (Acceso Feb 20/2015);14:45. Available at: https://scholar.google.es/scholar?hl=es\&as_sdt=0\%2C5\&q=Berro+G.+oblito\%2C\%3F\%60+responsabilidad+colectiva+o\%3F+Aspectos+m\%C3\%A9dicolegales\&btnG=.

13. Martínez-Velasco IG, Jiménez-López R, Veliz-Pradel N, Cadena-Vázquez MA, Reyes-García A. Oblitoma en la cirugía ginecoobstétrica: un problema creciente. Reporte de un caso. Ginecol Obstet México. 2017;85:202-11. Available at: https://www.medigraphic.com/cgi-bin/new/resumen.cgi? IDARTICULO=74229.

14. Rey S. 1. El Liderazgo en Patología. Arch Patol Número. 2020. Available at: https://www.archivosdepatologia.org/secciones/documentos/pdf/Archivos\%20de\%20Patologia\%20-\%20Junio\%202020\%20\%20Volumen\%201\%20Numero\%202\%20-\%2002\%20-\%20Liderazgo\%20en\%20Patologia.pdf.

15. Echevarría Zuno S, Sandoval Castellanos F, Gutiérrez Dorantes S, Alcantar Bautista A, Cote Estrada L. Eventos adversos en cirugía. Cir Gen. 2011;33:1639. Available at: http://www.scielo.org.mx/scielo.php?pid=S1405-00992011000300005\&script=sci_arttext.

16. Rodríguez LMB, Rico DAP, Ballesteros N, Rodríguez J, Carreño ZO, Bayona LG, et al. Frecuencia, evitabilidad y consecuencias de los eventos adversos. Rev Cienc Cuid. 2011;8:75-83. Available at: https://dialnet.unirioja.es/servlet/articulo?codigo=3853523.

17. Chavarriaga JCB. La eficiencia de la carga de la prueba en los procesos por responsabilidad médica en Colombia. La Ley: Revista jurídica española de doctrina, jurisprudencia y bibliografía, 1998, 1): 1928-1929. Available at: http://www.revistas.usb.edu.co/index.php/criterios/article/download/4071/3283/.

18. Muñoz Bravo MC. Responsabilidad del estado colombiano y posición jurisprudencial del consejo de estado frente al oblito en los años 1992 a 2017 (PhD Thesis). Universidad Santiago de Cali; 2018. Available at: https://repository.usc.edu.co/handle/20.500.12421/997.

19. Arocete Torres LC, Vargas Forero AM. Valor probatorio de la historia clínica en los procesos de responsabilidad médica. 2017. Available at: https://repository.unab.edu.co/handle/20.500.12749/535.

20. Park J, Woodrow SI, Reznick RK, Beales J, MacRae HM. Patient care is a collective responsibility: Perceptions of professional responsibility in surgery. Surgery [Internet]. 1 de julio de 2007 (citado 23 de enero de 2021);142:111-8. Available at: https://www.sciencedirect.com/science/article/pii/S0039606007001997.

21. Berlin L. Medical errors, malpractice, and defensive medicine: an ill-fated triad. Diagnosis (Internet). 26 de septiembre de 2017 (citado 24 de enero de 2021);4:133-9. Available at: https://www.degruyter.com/view/journals/dx/4/3/article-p133.xml.

22. Bunge M. La ciencia: su método y su filosofía. Vol. 1. Laetoli; 2018. Available at: https://books.google.es/books? $\mathrm{hl}=\mathrm{es} \& \mathrm{r}=\& \mathrm{id}=$ OgmMDWAAQBAJ\&oi=fnd\&pg=PT3\&dq=eBunge+M.+La+ciencia:+su+m\%C3\%A9todo+y+su+filosof\%C3\%ADa\&ots=fXxhrWXmZU\&sig=HWDsFxv5JFVuD4BtFPWLSCOOlk.

23. De Souza Minayo MC. El desafío del conocimiento. Investig Cual En Salud B Aires Lugar Editor. 1997; Available at: https://www.researchgate.net/profile/Maria_Minayo/publication/33023708_El_desafio_del_conocimiento_Investigacion_cualitativa_en_salud/links/569e1

24. Narváez VPD. Metodología de la investigación científica y bioestadística: para médicos, odontólogos y estudiantes de ciencias de la salud. RIL editores; 2009. Available at: https://books.google.es/books?

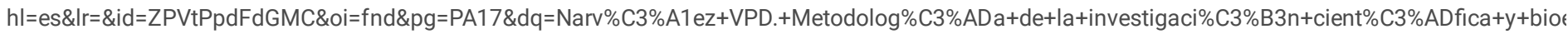
Uh4ZW0\&sig=GGCPX017NY2g5eQ836eyfvZh6gc.

25. Vásquez L, Rejane F, Amparo M, José FE, Ingrid V. Introducción a las técnicas cualitativas de investigación aplicadas en salud. Programa Editorial UNIVALLE; 2011. Available at: https://books.google.es/books?

$\mathrm{hl}=\mathrm{es} \& \mathrm{l}=\& \mathrm{id}=\mathrm{W}$ OnzDWAAQBAJ\&oi=fnd\&pg=PA5\&dq=V\%C3\%A1squez+L,+Rejane+F,+Amparo+M,+Jos\%C3\%A9+FE,+lngrid+V.+Introducci\%C3\%B3n+a+last _uZnlerdj\&sig=uE-AhVQJtnvr8bNZbzlPgGgLLjl.

26. Amir S, Vaswani VR, Vaswani R. Knowledge, Attitude, Practice about disclosure of medical errors among residents of a tertiary care hospital, Dakshina Kannada. Int J Health Sci Res. 2017;7:45-52. Available at: https://www.academia.edu/download/64416109/6.pdf.

27. Malterud K. Qualitative research: standards, challenges, and guidelines. Lancet. 2001;358:483-8. Available at: https://www.sciencedirect.com/science/article/pii/S0140673601056276.

28. Moen K, Middelthon AL. Qualitative research methods. En: Research in medical and biological sciences. Elsevier; 2015. p. 321-78. Available at: https://www.sciencedirect.com/science/article/pii/B9780127999432000100.

29. Yalma RM, Asuzu MC. Perception of practicing physicians on medical errors disclosure in government secondary and tertiary health facilities in Abuja Nigeria. International Journal of Recent Innovations in Medicine and Clinical Research. 2020;2:38-48. Available at:

https://ijrimcr.com/docs/2020/volume2/issue4/IJRIMCR-05.pdf.

30. Yassa HA, Peter AF. Medical error disclosure can rescue malpractice litigation. Arab J Forensic Sci Forensic Med. 2018;1:859-68. Available at: https://platform.almanhal.com/Files/2/127286.

31. Córdova JFA, Vásquez GC, Aguilar GAlH. Textilomas intra-abdominales. Frecuencia y actitud en el cirujano mexicano. Cir Gen. 2004;26:203-7. Available at: https://www.medigraphic.com/cgi-bin/new/resumen.cgi?IDARTICULO=24848.

Page $8 / 9$ 
32. Morbility derived from gauze forgetfulness in surgical acts. Revista CONAMED, 2008;13:5-11. Available at: https://www.medigraphic.com/cgi$\mathrm{bin} / \mathrm{new} /$ resumenl.cgi?IDREVISTA=334\&IDARTICULO=60650\&IDPUBLICACION=6024.

33. West CP, Tan AD, Habermann TM, Sloan JA, Shanafelt TD. Association of resident fatigue and distress with perceived medical errors. Jama. 2009;302:1294-300. Available at: https://jamanetwork.com/journals/jama/fullarticle/302/12/1294.

34. McDonald CJ, Weiner M, Hui SL. Deaths due to medical errors are exaggerated in Institute of Medicine report. Jama. 2000;284:93-5. Available at: https://jamanetwork.com/journals/jama/article-abstract/192843.

35. Leape LL. Institute of Medicine medical error figures are not exaggerated. Jama. 2000;284:95-7. Available at: https://jamanetwork.com/journals/jama/article-abstract/192842.

36. Berwick DM, Leape LL. Reducing errors in medicine: It's time to take this more seriously. British Medical Journal Publishing Group; 1999;319:136. Available at: https://doi.org/10.1136/bmj.319.7203.136.

37. Loue S. Medical error: truthtelling, apology, and forgiveness. Case Stud Soc Relig Bioeth. 2020;73-101. Available at: https://link.springer.com/chapter/10.1007/978-3-030-44150-0_4.

38. Altay B, Koç E. Determination of tendency of midwifery and nursing students towards medical malpractice. Bulgaria: Academic; 2017. p. 51-8. Available at:

https://www.researchgate.net/profile/Emine_Koc6/publication/347524273_Determination_of_Tendency_of_Midwifery_and_Nursing_Students_towards_M of-Tendency-of-Midwifery-and-Nursing-Students-towards-Medical-Malpractice-chapter-6.pdf.

39. Flug JA, Ponce LM, Osborn HH, Jokerst CE. Never events in radiology and strategies to reduce preventable serious adverse events. Radiographics. 2018;38:1823-32. Available at: https://pubs.rsna.org/doi/abs/10.1148/rg.2018180036.

40. Sukumaran S. Physician challenges in medical error disclosure-a case study in undergraduate medical student education. Glob Bioeth Enq. $2017 ; 35$. Available at: http://www.avlogiari.gr/files4users/files/GBE\%20FINAL\%20ISSUE.pdf\#page=40.

41. Helo S, Moulton CAE. Complications: acknowledging, managing, and coping with human error. Transl Androl Urol. 2017;6:773. Available at: https://www.ncbi.nIm.nih.gov/pmc/articles/PMC5583051/.

42. Banja JD. Patient safety ethics: How vigilance, mindfulness, compliance, and humility can make healthcare safer. JHU Press; 2019. Available at: https://books.google.es/books?

$\mathrm{hl}=$ es\&lr=\&id=ynSRDwAAQBAJ\&oi=fnd\&pg=PP1\&dq=Banja+JD.+Patient+safety+ethics:+How+vigilance,+mindfulness,+compliance,+and+humility+can+n

43. Stelfox HT. The impact of checklists on inpatient safety outcomes: a systematic review of randomized controlled trials. J Hosp Med. 2017;12:675-82. Available at: https://www.journalofhospitalmedicine.com/jhospmed/article/143603/hospital-medicine/impact-checklists-inpatient-safety-outcomessystematic.

44. Cohn T, Pryor A. Disclosure of medical errors and complications. En: Quality in obesity treatment. Springer; 2019. p. 309-16. Available at: https://link.springer.com/chapter/10.1007/978-3-030-25173-4_32.

45. Mena P. Error médico y eventos adversos. Rev Chil Pediatría. 2008;79:319-26. Available at: https://scielo.conicyt.cl/scielo.php?pid=S0370$41062008000300012 \&$ script=sci_arttext\&tlng=en.

46. Córdova-Pluma VH, Vega-López CA, Castillo-González FA, Cornejo-López GB, Ramírez-Arias JL, Rodríguez-Treviño C. Textiloma abdominal: reporte de caso. Med Interna México. 2012;28:398-402. Available at: http://search.ebscohost.com/login.aspx?

direct=true\&profile=ehost\&scope=site\&authtype=crawler\&jnl=01864866\&AN=88949405\&h=uRui51ep4yp8PTKHEzIXZ56V9jDX9KJh51 L9rpqHUQPn6Nrh4

47. Rojas Arroyo ME. Nivel de conocimientos de las funciones de la enfermera instrumentista y circulante y desempeño laboral en centro quirúrgico. 2016. Available at: http://dspace.unitru.edu.pe/handle/UNITRU/14413.

48. Camarena Nuñez RDP, Prado Camacho CJ, Vega Astuhuamán MJ. Relación entre conocimiento y actitudes del equipo quirúrgico en el manejo de medidas asépticas en centro quirúrgico de un hospital nacional. 2017. Available at: http://190.116.48.43/handle/upch/803.

\section{Supplementary Files}

This is a list of supplementary files associated with this preprint. Click to download.

- ResearchInterview.docx 